\title{
Effects of nitrogen load on the function and diversity of methanotrophs in the littoral wetland of a boreal lake
}

\author{
Henri M. P. Siljanen ${ }^{1,2}{ }^{*}$, Anne Saari ${ }^{1}$, Levente Bodrossy ${ }^{3 \dagger}$ and Pertti J. Martikainen ${ }^{1}$ \\ ' Department of Environmental Science, University of Eastern Finland, Kuopio, Finland \\ ${ }^{2}$ Finnish Environment Institute, Kuopio, Finland \\ ${ }^{3}$ Department of Bioresources/Microbiology, Austrian Institute of Technology, Seibersdorf, Austria
}

\section{Edited by:}

Svetlana N. Dedysh, Russian

Academy of Sciences, Russia

\section{Reviewed by:}

Ingeborg Bussmann,

Alfred-Wegener-Institut, Germany

Yin Chen, University of Warwick, UK

\section{${ }^{*}$ Correspondence:}

Henri M. P. Siljanen, Department of

Environmental Science, University of

Eastern Finland, P. O. Box 1627,

Fl-70211 Kuopio, Finland.

e-mail: henri.siljanen@uef.fi

\section{${ }^{\dagger}$ Present address:}

Levente Bodrossy, National Research

Flagship, CSIRO Marine and

Atmospheric Research and Wealth

from Oceans, Hobart, TAS, Australia.
Methane is the second most abundant greenhouse gas in the atmosphere. A major part of the total methane emissions from lake ecosystems is emitted from littoral wetlands. Methane emissions are significantly reduced by methanotrophs, as they use methane as their sole energy and carbon source. Methanotrophic activity can be either activated or inhibited by nitrogen. However, the effects of nitrogen on methanotrophs in littoral wetlands are unknown. Here we report how nitrogen loading in situ affected the function and diversity of methanotrophs in a boreal littoral wetland. Methanotrophic community composition and functional diversity were analyzed with a particulate methane monooxygenase (pmoA) gene targeted microarray. Nitrogen load had no effects on methane oxidation potential and methane fluxes. Nitrogen load activated pmoA gene transcription of type I (Methylobacter, Methylomonas, and LW21-freshwater phylotypes) methanotrophs, but decreased the relative abundance of type II (Methylocystis, Methylosinus trichosporium, and Methylosinus phylotypes) methanotrophs. Hence, the overall activity of a methanotroph community in littoral wetlands is not affected by nitrogen leached from the catchment area.

Keywords: methane, littoral wetland, methanotrophs, nitrogen, pmoA gene, pmoA transcript, pmoA microarray

\section{INTRODUCTION}

Methane $\left(\mathrm{CH}_{4}\right)$ is the second most abundant greenhouse gas in the atmosphere after carbon dioxide. It is 25 times more efficient (with a time horizon of 100 years) as a greenhouse gas than carbon dioxide (Denman et al., 2007). It accounts for about $20 \%$ of the radiative forcing (warming effect) of the atmosphere (Denman et al., 2007). In oxic surface layers of wetlands, methanotrophs, which are aerobic methane oxidizing bacteria, can consume more than $90 \%$ of the $\mathrm{CH}_{4}$ produced in deeper anoxic layers (Oremland and Culbertson, 1992), implementing an important ecosystem service.

Taxonomically, methanotrophs belong to two phyla, Verrucomicrobia and Proteobacteria (Semrau et al., 2010). Verrucomicrobial methanotrophs have been shown to live only in extreme conditions in geothermal environments (Op den Camp et al., 2009), so they are not of particular interest to this study. Proteobacterial methanotrophs are divided into two classes, Gammaproteobacteria and Alphaproteobacteria (often referred to as type I and type II methanotrophs, respectively) on the basis of phylogeny, physiology, morphology, and biochemistry (Semrau et al., 2010). Type I methanotrophs are further divided into type Ia and type Ib subgroups based on their phylogeny (Bodrossy et al., 2003).

Methane mono-oxygenases (MMO) of methanotrophs are the key enzymes in the $\mathrm{CH}_{4}$ oxidation process, and the phylogeny of MMO genes corresponds well with 16S rRNA gene-based phylogeny. The gene fragments of the particulate form of MMO, $p m o A$, and soluble form of MMO, $m m o X$, can be used for the detection of a diversity of methanotrophs and their $\mathrm{CH}_{4}$ oxidation activity. Almost all methanotrophs possess the pmoA gene, and strains lacking it can be detected by $m m o X$-targeted approaches (Dedysh et al., 2005; Rahman et al., 2011; Vorobev et al., 2011). Most methanotrophs use only methane as their carbon and energy source, but some strains of Alphaproteobacteria methanotrophs have been shown to grow also with $\mathrm{C}_{2}$ substrates (Dedysh et al., 2005; Dunfield et al., 2010; Belova et al., 2011).

A littoral zone can contribute as much as $70 \%$ of the total $\mathrm{CH}_{4}$ emissions of lakes (Juutinen et al., 2003). Nitrogen (N) can either inhibit (Steudler et al., 1989) or stimulate (Bodelier et al., 2000) $\mathrm{CH}_{4}$ oxidation and subsequently cause higher or lower $\mathrm{CH}_{4}$ emissions. Both responses are possible in upland and wetland soils but the mechanisms behind the different effects are not fully understood (Bodelier and Laanbroek, 2004). Littoral wetlands, which are under the influence of the fluctuating water levels of lakes, are the target of $\mathrm{N}$ leached from the catchment. If $\mathrm{N}$ inhibits $\mathrm{CH}_{4}$ oxidation, the $\mathrm{CH}_{4}$ emissions from littoral wetlands can increase. However, the effects of nitrogen on the function and diversity of methanotrophs at the species level in littoral wetlands are unknown.

We studied the effects of experimental nitrogen loading in situ on the function and diversity of methanotrophs and fluxes of $\mathrm{CH}_{4}$ in a boreal littoral wetland during a growing season. The relative abundance of $p m o A$ genes and gene transcripts was examined with a $p m o A$ targeting diagnostic microarray (Bodrossy et al., 2003).

\section{MATERIALS AND METHODS STUDY SITE}

The studied littoral wetland of the hypereutrophic Lake Kevätön is located in Eastern Finland $\left(63^{\circ} 6^{\prime} \mathrm{N}, 27^{\circ} 37^{\prime} \mathrm{E}\right)$. Since 
spatial variation contributes to the function and diversity of methanotrophs, six (three for $\mathrm{N}$ fertilization and three for control) study plots of $1.44 \mathrm{~m}^{2}$ were randomly established in the "intermediate" area of the wetland, i.e., in the area 7-10 $\mathrm{m}$ from the shoreline (Siljanen et al., 2011). This area has only minor spatial variation in hydrology and distribution of vegetation. The vegetation consists mainly of sedges and it did not vary among the study plots (variances were tested by the Kruskal Wallis rank sum test, $P>0.35$ ). The water level variation did not differ statistically significantly between the control and manipulated plots (Mixed model, $P>0.124 \ldots 0.421)$ although the N-treated plots had a slightly lower water table than the control plots (Figure A4 in Appendix).

\section{SOIL SAMPLING, NITROGEN LOAD, BIOGEOCHEMICAL ANALYSES, AND NUCLEIC ACID EXTRACTIONS FROM THE SOILS}

Soil samples were taken on June 7, July 7, and August 16, 2007 from triplicate nitrogen and control plots. Nitrogen treatment $\left(\mathrm{NH}_{4} \mathrm{NO}_{3}\right.$ dissolved in distilled $\mathrm{H}_{2} \mathrm{O}$, total dose $10 \mathrm{~g} \mathrm{~N} \mathrm{~m}^{-2}$, corresponds with $100 \mathrm{~kg} \mathrm{~N} \mathrm{ha}^{-1}$ ) was done four times during the 2007 growing season with 1 week intervals $\left(2.5 \mathrm{~g} \mathrm{~N} \mathrm{~m}^{-2}\right.$ each dose). Control plots received similar amounts of water (distilled $\mathrm{H}_{2} \mathrm{O}$ ) as the nitrogen treated plots. The first soil samples were taken 14 days before the first nitrogen dose. The second soil samples were taken 14 days after the start of the nitrogen loading, when 50\% $\left(5.0 \mathrm{~g} \mathrm{~N} \mathrm{~m}^{-2}\right)$ of the total nitrogen dose was applied (Figure A1 in Appendix). The last soil samples were collected 6 days after the nitrogen loading. Soil profiles were taken with a box corer (diameter $8 \mathrm{~cm} \times 8 \mathrm{~cm}$ ) from the plots and divided into 0-2, 210 , and $10-20 \mathrm{~cm}$ layers. Methane fluxes, $\mathrm{CH}_{4}$ oxidation potential, and soil chemical characteristics (nitrate and ammonium concentrations) were determined as described previously (Siljanen et al., 2011). From each soil layer, $15 \mathrm{ml}$ sub-samples were collected for molecular analyses of the methanotrophic community and were frozen immediately with dry ice at the study site. Soil was freeze-dried $\left(-50^{\circ} \mathrm{C}, 48 \mathrm{~h}\right)$. DNA extractions were performed as described previously (Siljanen et al., 2011). RNA extractions and clean-up were done according to a protocol described by Steenbergh et al. (2010) with minor modifications: contaminating DNA was removed according to the manufacturer's instructions with DNase I and cDNA synthesis with RevertAid MuLV-H reverse transcriptase, both provided by Fermentas.

\section{MOLECULAR ANALYSES OF METHANOTROPHS}

PCR products of $p m o A$ genes for microarray analysis were amplified with a semi-nested approach with reaction mixtures and cycling conditions, as described earlier (Siljanen et al., 2011). The primers used for the semi-nested approach were A189 (5'-GGNGACTGGGACTTCTGG-3'), A682T7 (5' -TAATACGACTCACTATAGGAASGCNGAGAAGAASGC$3^{\prime}$ ), and mb661-T7 (5' -TAATACGACTCACTATAGCCGGMGCAA CGTCYTTACC- $\left.3^{\prime}\right)$. The relative abundance of $p m o A$ genes and gene transcripts was examined with a $p m o A$ microarray as described previously (Bodrossy et al., 2003). The presence of Methylocella and Methylocella-like methanotrophs was determined with a PCR method (Rahman et al., 2011). For amplification, $2 \times$ Premix F (Epicentre), 1 unit of Taq polymerase (Invitrogen), and $50 \mathrm{ng}$ of template DNA or cDNA were used.
For amplification of $p m o A$ genes 25 pmol of each primer was used, and $40 \mathrm{pmol}$ of each primer was used for mmoX genes. Reactions were carried out in $50 \mu \mathrm{l}$ volume. The PCR cycling conditions for Methylocella primers were the following: denaturation $95^{\circ} \mathrm{C}, 15 \mathrm{~s}$, annealing $68^{\circ} \mathrm{C}, 1 \mathrm{~min}$, elongation $72^{\circ} \mathrm{C}, 1 \mathrm{~min}$ for 45 cycles. The primers used for Methylocella PCR were mmoXLF (5'-GAAGATTGGGGCGGCATCTG-3') and mmoXLR (5'-CCCAATCATCGCTGAAGGAGT-3'; Rahman et al., 2011). Cloned fragments of $m m o X$ genes of Methylocella palustris were used as a positive control for the assay. For analysis of the diversity of Methylocella methanotrophs, PCR products were ligated to a pDRIVE vector and cloned, as described previously (Siljanen et al., 2011). Clones were subjected to restriction fragment length polymorphism (RFLP). In RFLP analysis, DNA of clones was digested with SalI and Bam HI restriction enzymes and restriction patterns were visualized with electrophoresis in a $2.5 \%(\mathrm{w} / \mathrm{v})$ agarose gel. Clones displaying identical restriction patterns were grouped into operational taxonomical units (OTUs). One to two clones per OTUs were sequenced. DNA sequencing was performed at the University of Eastern Finland Sequencing Laboratory with the MegaBACE 750 analysis system with a DYEnamic ${ }^{\text {TM}}$ ET Dye Terminator Cycle Sequencing Kit. The identity of clones was examined by BLASTn searches of the GenBank database (Altschul et al., 1990).

\section{STATISTICAL ANALYSIS}

The effects of the manipulation on $\mathrm{CH}_{4}$ fluxes, $\mathrm{CH}_{4}$ oxidation, and on the responses of community composition and functional diversity of methanotrophs at the species level were analyzed with a mixed-effect model (proportional to a repeated measure ANOVA; Laird and Ware, 1982). Amplification of pmoA genes for four cDNA replicates (10-20 cm layer, mainly clay with negligible $\mathrm{CH}_{4}$ oxidation potential) did not succeed even though re-extraction was performed. In these cases, duplicates instead of triplicates were used for the analysis. For evaluating the effect of nitrogen at the species level of methanotrophs, 1020 mixed-effect models were calculated, one model for both manipulated and control plots and for each of 85 microarray probes showing positive signals. Prior to the analysis, the microarray data were square-root transformed. The effects of nitrogen loading were evaluated with the difference between the models of the manipulated and control plots (see example of model results in Figure A3 in Appendix). The normality of residuals was tested for each variable group to fulfill the requirements of the analysis set-up. Mixed-effect model tests were done with the statistical program SPSS 17.0 (SPSS Inc., USA). The relation between the change in the methanotroph community (both community composition and functional diversity), $\mathrm{CH}_{4}$ oxidation and nitrogen load was studied with constrained correspondence analysis (CCA). CCA analyses were performed for those microarray probes showing change. The analysis included the probes Mb271, Mb C11-403, Mm531, MmES546, Ia 193, Ia 575, LW21-374, LW21-391, Ib453, Mcy233, Mcy413, Mcy264, Mcy459, Mcy255, McyM309, MsT214, Msi269, MsS314, Msi423, Msi294, and NMsiT-271. The probes targeting the RA14 group (probe RA14-591) and Methycapsa (probes B2all343, B2all341) were omitted from the analysis because of lack of hybridization to species-specific probes (RA14-594, B2-400). Constrained 


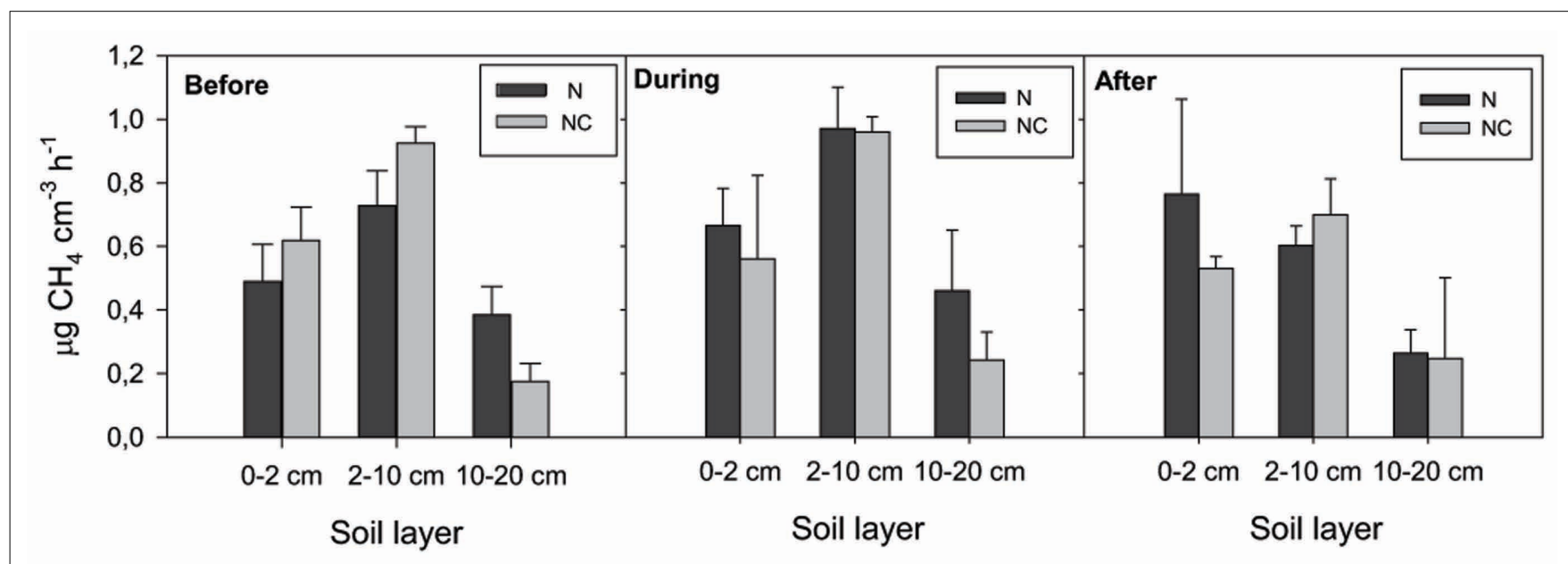

FIGURE 1 | Methane oxidation potential. N denotes nitrogen loading plots and NC control plots. Fixed effect of nitrogen load: $F_{0-2 \mathrm{~cm} \text { layer }}=0.105, P=0.762$; $F_{2-10 \mathrm{~cm} \text { layer }}=0.821, P=0.416 ; F_{10-20 \mathrm{~cm} \text { layer }}=2.035, P=0.227$.

correspondence analyses were conducted with the VEGAN (Oksanen et al., 2010) add-on package in the R 2.12.0 statistical program (R Development Core Team, 2010). The Pearson correlation coefficients between nitrate and ammonium concentrations, $\mathrm{CH}_{4}$ oxidation potential, and microarray data were also calculated with the R program.

\section{RESULTS \\ EFFECTS OF NITROGEN ON CH${ }_{4}$ OXIDATION AND $\mathrm{CH}_{4}$ FLUXES}

Nitrogen loading increased nitrate $\left(F_{\text {nitrate }}=12.792, P<0.005\right.$, maximum in loaded plots was $6 \mu \mathrm{g} \mathrm{NO}_{3}^{-}-\mathrm{N} \mathrm{cm}^{-3}$ ) concentration in the 0 - to $2-\mathrm{cm}$ soil layer (Figure A2 in Appendix). Ammonium concentration increased also slightly in this layer $\left(F_{\text {ammonium }}=4.366, P=0.059\right.$, the maximum in the loaded plots was $25 \mu \mathrm{g} \mathrm{NH}_{4}^{+}-\mathrm{N} \mathrm{cm}^{-3}$ ) as well as in the deeper layers $\left(2-10 \mathrm{~cm}\right.$ layer $F_{\text {ammonium }}=3.409, P=0.090 ; 10-20 \mathrm{~cm}$ layer $F_{\text {ammonium }}=3.825, P=0.076$; Figure A2 in Appendix). Nitrogen load did not affect $\mathrm{CH}_{4}$ oxidation potential statistically significantly but $\mathrm{CH}_{4}$ oxidation increased during the experimental season in the 0 - to $2-\mathrm{cm}$ layer in both control and manipulated plots (Figure 1) as a result of changing environmental conditions (natural lowering in water table, Figure A4 in Appendix). Nitrogen loading had no significant effect also on the $\mathrm{CH}_{4}$ fluxes which decreased in both control and manipulated plots toward autumn as a result of the decrease in water level (Figure A4 in Appendix). The relative decrease in methane fluxes was higher in the $\mathrm{N}$-treated plots (Figure 2) also indicating that nitrogen load did not inhibit methane oxidation.

\section{EFFECTS OF NITROGEN ON THE METHANOTROPHIC COMMUNITY}

The methanotrophic community structure was close the same in the manipulated and control plots before nitrogen loading, only a few phylotypes showed some variation (14 days before fertilization started; Figure 3A). Nitrogen loading changed the community structure and functional diversity of methanotrophs as revealed by mixed-effect models (Figure 3A) and CCA analysis (Figures 3B-D). When the site had received $50 \%$ of the total

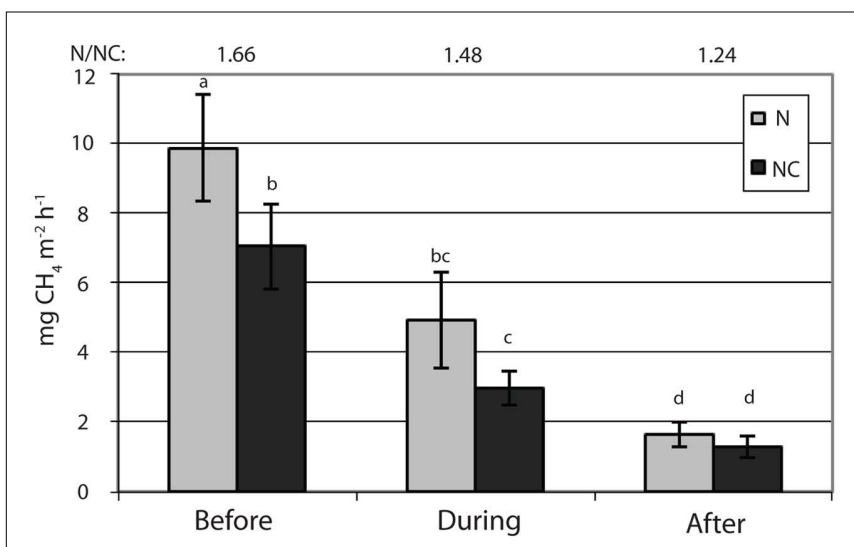

FIGURE 2 | Methane fluxes. $\mathrm{N}$ denotes nitrogen loading plots and NC control plots. Fixed effect of nitrogen load: $F=2.3, P=0.204$. Significant differences in fluxes are marked with letters $(P<0.05)$. The ratio of methane fluxes in the nitrogen loaded plots to those in the control plots are shown by numbers on top of the figure.

nitrogen load there was a decrease in the relative abundance of pmoA genes of type II (Methylocystis, Methylosinus trichosporium, and Methylosinus phylotypes, $P<0.05)$ methanotrophs in the 0 to $10-\mathrm{cm}$ soil layers (Figure 3A; Figure A3A in Appendix). There was also an increase in the relative abundance of $p m o A$ transcripts of type I (Methylobacter, Methylomonas, and LW21-freshwater phylotypes, $P<0.05$ ) methanotrophs in the 2 - to $10-\mathrm{cm}$ soil layer (Figure 3A; Figure A3B in Appendix). CCA multivariate ordination analysis revealed a correlation between the concentrations of ammonium and nitrate and microarray data measured during nitrogen loading in affected soil layers and gene pools, as samples during the experiment are clustered together with the ordinated arrows for ammonium and nitrate (Figures 3B-D). Manipulation had the strongest effect on the community in the 2 - to $10-\mathrm{cm}$ soil layer (Figures $3 \mathbf{C , D}$ ), and nitrate also had an effect on functional diversity after the experiment (Figure 3D). 


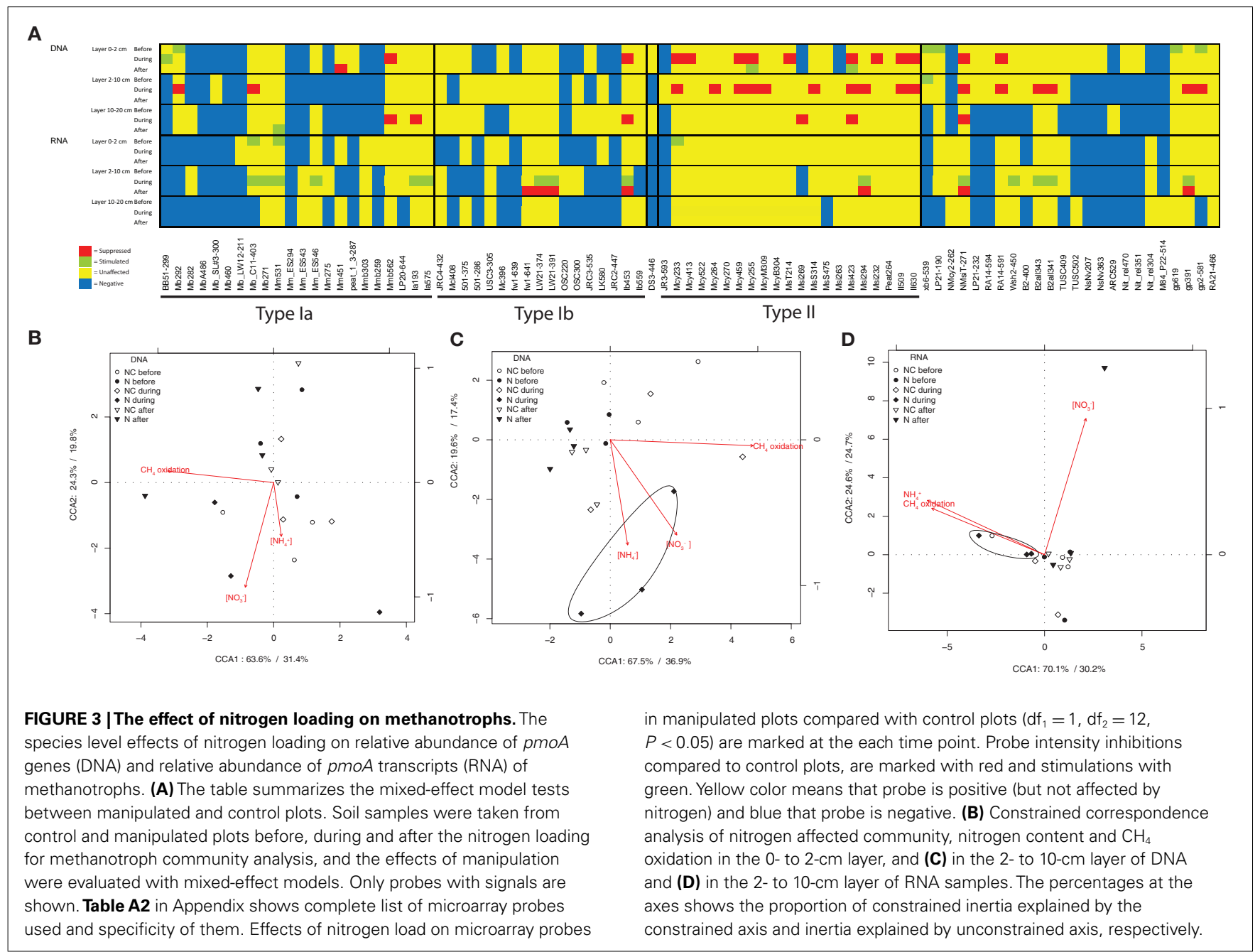

However, methanotrophic community also shows seasonal variation in the littoral wetland (Siljanen et al., 2012), and this variation was taken into account by comparing the nitrogen loading plots with non-treated control plots.

The effects of nitrogen loading on the methanotrophic community were also examined more deeply with correlation analysis for the relative abundance of $p m o A$ genes and gene transcripts (Table A1 in Appendix). The relative abundance of the $p m o A$ genes and gene transcripts of type I methanotrophs correlated positively with the content of ammonium and nitrate, while pmoA transcripts of type II methanotrophs correlated negatively with ammonium (Table A1 in Appendix). Across the experiment, type I and type II methanotrophs had opposite correlations with $\mathrm{CH}_{4}$ oxidation, suggesting differences in the reactions of the taxonomical groups to nitrogen (Table A1 in Appendix).

\section{DISCUSSION}

Methane fluxes declined similarly in the control and manipulated plots over the study period because of the decrease in water level toward autumn. Nitrogen load had no statistically significant effects on either $\mathrm{CH}_{4}$ oxidation potential or $\mathrm{CH}_{4}$ fluxes in the littoral wetland, suggesting that the overall activity

of methanotrophic communities there was not disturbed by nitrogen, although the methanotrophic community structure was affected. Similar observations on the tolerance of methane oxidation against nitrogen have been made previously in other soil types (Dunfield et al., 1995; Delgado and Mosier, 1996; Cai and Yan, 1999; Bykova et al., 2007).

As in our littoral wetland, nitrogen has been reported to inhibit type II methanotrophs in forest (Mohanty et al., 2006) and field soils (Cébron et al., 2007). The activity of type I methanotrophs was stimulated by nitrogen load in the present study as has been found in rice field soil (Bodelier et al., 2000; Mohanty et al., 2006; Noll et al., 2008; Shrestha et al., 2010) and in forest soil at high methane concentrations (Mohanty et al., 2006). Nitrogen leached from agricultural soils (Riley et al., 2001; Pare et al., 2006) to littoral wetlands evidently does not inhibit $\mathrm{CH}_{4}$ oxidation because methanotrophic communities there are dominated by type I methanotrophs (Siljanen et al., 2011).

In the littoral wetland, $p m o A$ gene transcription of type I methanotrophs was stimulated but not the relative abundance of these methanotrophs, indicating the existence of factors limiting the increase in their number. It can be that type I 
methanotrophs are nitrogen limited in the littoral wetland and subsequently stimulated by nitrogen load (see later) similarly to the rhizosphere of rice (Bodelier et al., 2000). Selective grazing by protists on type I methanotrophs (Murase and Frenzel, 2008) may be another reason for the lack of increase in their relative abundance.

It has been suggested that the inhibition of type II methanotrophs by nitrogen is due to competition between different types of methanotrophs (Cébron et al., 2007). In nitrogen-rich conditions, type I methanotrophs could outcompete type II methanotrophs. This can be associated to the better ability of type II methanotrophs to fix molecular nitrogen, which lowers their need for ammonium and nitrate (Murrell and Dalton, 1983). Thus, type I methanotrophs can increase their $\mathrm{CH}_{4}$ oxidation activity by nitrogen addition in nitrogen-limited environments. Biomass production of wetland plants in the littoral wetland studied is high (Larmola et al., 2003) causing high demand for nitrogen, and nitrogen can also be efficiently removed by denitrification in wetland. Competition for nitrogen there is thus high.

A similar inhibitory effect of nitrogen on type II methanotrophs, as in the littoral wetland here, has been detected among Methylocystis methanotrophs (Mohanty et al., 2006; Cébron et al., 2007). In the littoral wetland, Methylosinus and M. trichosporium methanotrophs were also inhibited (Figure 3A). However, nitrogen loading increased the relative abundance of $p m o A$ transcripts of one Methylosinus phylotype (Msi294). The results of the present study support the findings that nitrogen can reduce $\mathrm{CH}_{4}$ oxidation if type II methanotrophs dominate the methanotrophic community (Mohanty et al., 2006).

Since the microarray method depicts the relative abundance in methanotrophic communities, a change in the relative abundance of type II methanotrophs could be a result either of an increase in the relative abundance of type I methanotrophs over type II methanotrophs, or a decrease in the relative abundance of type II methanotrophs. However, microarray data indicated no distinctive co-increase of type I methanotrophs during the experiment when inhibition of type II methanotrophs took place (Figure A3A in Appendix), suggesting that type II methanotrophs have been inhibited by nitrogen load as such, not through competition between type I and type II methanotrophs. However, it is important to note that the methanotrophic community of the littoral wetland reacted rapidly to nitrogen load and acclimated to the prevailing conditions. The shift in the methanotroph community took place within 14 days after the start of the nitrogen loading, and the community recovered soon after the loading ended (Figure 3A). This reveals the ability of methanotrophic community in the littoral wetland to withstand environmental changes and perturbations.

\section{REFERENCES}

Altschul, S. F., Gish, W., Miller, W., Myers, E. W., and Lipman, D. J. (1990). Basic local alignment search tool. J. Mol. Biol. 215, 403-410.

Belova, S. E., Baani, M., Suzina, N. E., Bodelier, P. L. E., Liesack, W., and

The semi-nested PCR approach and microarray probe set-up targeted type I and type II methanotrophs as well as RA14 members of upland soil cluster $\alpha$ (USC $\alpha$ ) methanotrophs and Methylocapsa methanotrophs but excluded Crenothrix, Methylocella, and Verrucomicrobia methanotrophs. However, it was proven by analysis of A682 PCR products with the pmoA microarray (detects Crenothrix, Siljanen et al., 2011) that Crenothrix methanotrophs were not present in that part of the wetland studied here (data not shown). Thus, Crenothrix may play a role in littoral wetlands but only in the areas with a higher water table than that in the area used in this study (Siljanen et al., 2011). Methylocella specific primers mmoXLF/R (Rahman et al., 2011) showed only a few negligible and very faint products from DNA samples and none from RNA samples. Therefore, although Methylocella methanotrophs are found in the littoral wetland, they play only a limited role in the $\mathrm{CH}_{4}$ oxidation.

The studied littoral wetland has a moderately high diversity of methanotrophs: 47 OTUs with $93 \%$ similarity (Siljanen et al., 2011), compared with other environments: 26 OTUs in temperate forest soils, 93\% similarity (Degelmann et al., 2010), and about 35 OTUs, $90 \%$ similarity, in rice field soils (Lüke et al., 2010). Since the sub-communities of this diverse community in the littoral wetland react differently to nitrogen load, the overall effect of nitrogen loading was neutral, causing no change in $\mathrm{CH}_{4}$ oxidation potential or $\mathrm{CH}_{4}$ fluxes.

There are only a few studies where the effects of nitrogen on $\mathrm{CH}_{4}$ fluxes and the methanotrophic community composition in situ have been studied simultaneously. Previous studies have investigated the effects of nitrogen load on the functioning and diversity of methanotrophs using microcosms and incubation experiments (Bodelier et al., 2000; Mohanty et al., 2006; Cébron et al., 2007; Noll et al., 2008; Shrestha et al., 2010). Here we provide new insights into how the nitrogen load affects the methanotrophic community and its functioning in situ.

In conclusion, methane oxidation in boreal littoral wetland tolerates nitrogen load as a result of diverse methanotrophic community. Although some methanotrophs are suffered by nitrogen, there are methanotrophs responding positively to extra nitrogen.

\section{ACKNOWLEDGEMENTS}

We thank S. Hämäläinen, K. Martikainen, T. Rahkonen, N. Partanen, R. Laroma, N. Stralis-Pavese, and G. C. J. Abell for technical assistance, and V. Paganuzzi for comments on the language of the manuscript. The academy of Finland (ESF and EuroDIVERSITYMETHECO), the Maj and Tor Nessling Foundation, the Niemi Foundation, Maa-ja vesitekniikan tuki association, and the Kone Foundation are acknowledged for financial support. Research at AIT was supported by the ESF EuroDiversity program METHECO (No. FP018, local funding agencies: FWF, Austria, project number I40-B06).

sediments. FEMS Microbiol. Ecol. 47, 265-277.

tion as a survival strategy of peat inhabiting Methylocystis spp. Environ. Microbiol. Rep. 3, 36-46.

Bodelier, P. L. E., and Laanbroek, H. J. (2004). Nitrogen as a regulatory factor of methane oxidation in soils and
Bodelier, P. L. E., Roslev, P., Henckel, T., and Frenzel, P. (2000). Stimulation by ammonium-based fertilizers of methane oxidation in soil around rice roots. Nature 403, 421-424.
Bodrossy, L., Stralis-Pavese, N., Murrell, J. C., Radajewski, S., Weilharter, A., and Sessitsch, A. (2003). Development and validation of a diagnostic microbial microarray for methanotrophs. Environ. Microbiol. 5, 566-582. 
Bykova, S., Boeckx, P., Kravchenko, I., Galchenko, V., and Van Cleemput, O. (2007). Response of CH4 oxidation and methanotrophic diversity to $\mathrm{NH} 4+$ and $\mathrm{CH} 4$ mixing ratios. Biol. Fertil. Soils 43, 341-348.

Cai, Z. C., and Yan, X. Y. (1999). Kinetic model for methane oxidation by paddy soil as affected by temperature, moisture and $\mathrm{N}$ addition. Soil Biol. Biochem. 31, 715-725.

Cébron, A., Bodrossy, L., Stralis-Pavese, N., Singer, A. C., Thompson, I. P., Prosser, J. I., and Murrell, J. C. (2007). Nutrient amendments in soil DNA stable isotope probing experiments reduce the observed methanotroph diversity. Appl. Environ. Microbiol. 73, 798-807.

Dedysh, S. N., Knief, C., and Dunfield, P. F. (2005). Methylocella species are facultatively methanotrophic. Environ. Microbiol. 187, 4665-4670.

Degelmann, D. M., Borken, W., Drake, H. L., and Kolb, S. (2010). Different atmospheric methane-oxidizing communities in European beech and Norway spruce soils. Appl. Environ. Microbiol. 76, 3228-3235.

Delgado, J. A., and Mosier, A. R. (1996). Mitigation alternatives to decrease nitrous oxides emissions and ureanitrogen loss and their effect on methane flux. J. Environ. Qual. 25, 1105-1111.

Denman, K. L., Brasseur, G., Chidthaisong, A., Ciais, P., Cox, P. M., Dickinson, R. E., Hauglustaine, D., Heinze, C., Holland, E., Jacob, D., Lohmann, U., Ramachandran, S., da Silva Dias, P. L., Wofsy, S. C., and Zhang, X. (2007). "Couplings between changes in the climate system and biogeochemistry," in Climate Change 2007: The Physical Science Basis. Contribution of Working Group I to the Fourth Assessment Report of the Intergovernmental Panel on Climate Change, eds S. Solomon, D. Qin, M. Manning, Z. Chen, M. Marquis, K. B. Averyt, M. Tignor, and $\mathrm{H}$. L. Miller (Cambridge: Cambridge University Press), 500-587.

Dunfield, P. F., Belova, S. E., Vorob'ev, A. V., Cornish, S. L., and Dedysh, S. N. (2010). Methylocapsa aurea sp. nov., a facultatively methanotrophic bacterium possessing a particulate methane monooxygenase. Int.
J. Syst. Evol. Microbiol. 60, 2659-2664.

Dunfield, P. F., Topp, E., Archambault, C., and Knowles, R. (1995). Effect of nitrogen fertilizers and moisturecontent on $\mathrm{CH} 4$ and $\mathrm{N} 2 \mathrm{O}$ fluxes in a humisol-measurements in the field and intact soil cores. Biogeochemistry 29, 199-222.

Juutinen, S., Alm, J., Larmola, T., Huttunen, J. T., Morero, M., Martikainen, P. J., and Silvola, J. (2003). Major implication of the littoral zone for methane release from boreal lakes. Global Biogeochem. Cycles 17, 1117.

Laird, N. M., and Ware, J. H. (1982). Random-effects models for longitudinal data. Biometrics 38, 963-974.

Larmola, T., Alm, J., Juutinen, S., Martikainen, P. J., and Silvola, J. (2003). Ecosystem $\mathrm{CO} 2$ exchange and plant biomass in the littoral zone of a boreal eutrophic lake. Freshw. Biol. 48, 1295-1310.

Lüke, C., Krause, S., Cavigiolo, S., Greppi, D., Lupotto, E., and Frenzel, P. (2010). Biogeography of wetland rice methanotrophs. Environ. Microbiol. 12, 862-872.

Mohanty, S. R., Bodelier, P. L. E., Floris, V., and Conrad, R. (2006). Differential effects of nitrogenous fertilizers on methane consuming microbes in rice field and forest soils. Appl. Environ. Microbiol. 72, 1346-1354.

Murase, J., and Frenzel, P. (2008). Selective grazing of methanotrophs by protozoa in a rice field soil. FEMS Microbiol. Ecol. 65, 408-414.

Murrell, J. C., and Dalton, H. (1983). Nitrogen fixation in obligate methanotrophs. J. Gen. Microbiol. 129, 3481-3486.

Noll, M., Frenzel, P., and Conrad, R. (2008). Selective stimulation of type I methanotrophs in a rice paddy soil by urea fertilization revealed by RNA-based stable isotope probing. FEMS Microbiol. Ecol. 65, 125-132.

Oksanen, J., Blanchet, F. G., Kindt, R., Legendre, P., O’Hara, R. B., Simpson, G. L., Solymos, P., Stevens, M. H. H., and Wagner, H. (2010). vegan: Community Ecology Package. $R$ package version 1.17-4. Available at: http://CRAN.R-project.org/ package $=$ vegan

Op den Camp, H. J. M., Islam, T., Stott, M. B., Harhangi, H. R., Hynes,
A., Schouten, S., Jetten, M. S. M. Birkeland, N. K., Pol, A., and Dunfield, P. F. (2009). Environmental genomic and taxonomic perspectives on methanotrophic Verrucomicrobia. Environ. Microbiol. Rep. 1 293-306.

Oremland, R. S., and Culbertson, C. W. (1992). Importance of methaneoxidizing bacteria in the methane budget as revealed by the use of specific inhibitor. Nature 356, 421-423.

Pare, K., Chantigny, M. H., Carey, K., Johnston, W. J., and Dionne, J. (2006). Nitrogen uptake and leaching under annual bluegrass ecotypes and bentgrass species: a lysimeter experiment. Crop Sci. 46 , 847-853.

R Development Core Team. (2010). $R:$ A language and environment for statistical Computing 2.12.0. Vienna: $\mathrm{R}$ Foundation for Statistical Computing. Available at: http://www.R-project.org

Rahman, M. T., Crombie, A., Chen, Y., Stralis-Pavese, N., Bodrossy, L., Meir, P., McNamara, N. P., and Murrell, J. C. (2011). Environmental distribution and abundance of the facultative methanotroph Methylocella. ISME J 5, 1061-1066.

Riley, W. J., Ortiz-Monasterio, I., and Matson, P.A. (2001). Nitrogen leaching and soil nitrate, nitrite, and ammonium levels under irrigated wheat in Northern Mexico. Nutr. Cycl. Agroecosys. 61, 223-236.

Semrau, J. D., DiSpirito, A. A., and Yoon, S. (2010). Methanotrophs and copper. FEMS Microbiol. Rev. 34, 496-531.

Shrestha, M., Shrestha, P. M., Frenzel, P., and Conrad, R. (2010). Effect of nitrogen fertilization on methane oxidation, abundance, community structure, and gene expression of methanotrophs in the rice rhizosphere. ISME J. 4, 1545-1556.

Siljanen, H. M. P., Saari, A., Bodrossy, L. and Martikainen, P. J. (2012). Seasonal variation in the function and diversity of methanotrophs in the littoral wetland of a boreal eutrophic lake. FEMS Microbiol. Ecol. (in press).

Siljanen, H. M. P., Saari, A., Krause, S. Lensu, A., Abell, G. C. J., Bodrossy, L., Bodelier, P. L. E., and Martikainen, P. J. (2011). Hydrology is reflected in the functioning and community composition of methanotrophs in the littoral wetland of a boreal lake. FEMS Microbiol. Ecol. 75, 430-445.

Steenbergh, A. K., Meima, M. M., Kamst, M., and Bodelier, P. L. E. (2010). Biphasic kinetics of a methanotrophic community is a combination of growth and increased activity per cell. FEMS Microbiol. Ecol. 71, 12-22.

Steudler, P. A., Bowden, R. D., Melillo, J. M., and Aber, J. D. (1989). Influence of nitrogen fertilization on methane uptake in temperate forest soils. Nature 341, 314-316.

Vorobev, A. V., Baani, M., Doronina, N. V., Brady, A. L., Liesack, W., Dunfield, P. F., and Dedysh, S. N. (2011). Methyloferula stalleta gen. nov., sp. nov., and acidophilic, obligately methanotrophic bacterium possessing only a soluble methane monooxygenase. Int. J. Syst. Evol. Microbiol. 61, 2456-2463.

Conflict of Interest Statement: The authors declare that the research was conducted in the absence of any commercial or financial relationships that could be construed as a potential conflict of interest. Nucleotide sequence accession numbers: sequences from this study are under Accession numbers HE653916-HE653917 in the EMBLbank.

Received: 25 November 2011; accepted: 24 January 2012; published online: 20 February 2012.

Citation: Siljanen HMP, Saari A, Bodrossy $L$ and Martikainen PJ (2012) Effects of nitrogen load on the function and diversity of methanotrophs in the littoral wetland of a boreal lake. Front. Microbio. 3:39. doi: 10.3389/fmicb.2012.00039

This article was submitted to Frontiers in Terrestrial Microbiology, a specialty of Frontiers in Microbiology.

Copyright (C) 2012 Siljanen, Saari, Bodrossy and Martikainen. This is an open-access article distributed under the terms of the Creative Commons Attribution Non Commercial License, which permits non-commercial use, distribution, and reproduction in other forums, provided the original authors and source are credited. 


\section{APPENDIX}

Table A1 | Pearson correlation co-efficients across the experiment between methanotroph relative abundance of pmoA genes/pmoA transcripts, $\mathrm{CH}_{4}$ oxidation potential, and concentration of nitrate/ammonium $(n=18)$.

\begin{tabular}{|c|c|c|c|}
\hline & $\mathrm{CH}_{4}$ oxidation & {$\left[\mathrm{NO}_{3}^{-}\right]$} & {$\left[\mathrm{NH}_{4}^{+}\right]$} \\
\hline DNA: 0-2 cm layer & $\begin{array}{l}\text { Type I probes: } \\
\text { Mb_C11-403, } r=0.70, P<0.01\end{array}$ & $\begin{array}{l}\text { Type I probes: } \\
\text { BB51-299, Mb_SL\#3-300, DS3-446, } \\
r=0.77 \ldots 0.89, P<0.001\end{array}$ & \\
\hline DNA: 2-10 cm layer & $\begin{array}{l}\text { Type I probes: } \\
\text { fw1-641, P_LW21-391, LK580, } \\
\text { Ib453. } r=-0.54 \ldots-0.63, P<0.05 \\
\text { Type II probes: } \\
\text { Mcy_264, Msi_294, II509, } \\
r=-0.51 \ldots-0.57, P<0.05\end{array}$ & $\begin{array}{l}\text { Type I probe: } \\
\text { Mb_SL\#3-300, } r=0.71, P<0.01\end{array}$ & \\
\hline RNA: 0-2 cm layer & & $\begin{array}{l}\text { Type I probes: } \\
\text { Mm451, 501-375, fw1-641, } \\
r=0.63 \ldots 0.89, P<0.05\end{array}$ & $\begin{array}{l}\text { Type II probes: } \\
\text { Mcy413, Mcy522, Mcy459, Msi232, } \\
\text { Peat264, } r=-0.49 \ldots-0.53, P<0.05\end{array}$ \\
\hline RNA: 2-10 cm layer & $\begin{array}{l}\text { Type I probes: } \\
\text { Mb282, Mb_C11-403, Mm275, } \\
r=0.50 \ldots 0.52, P<0.05\end{array}$ & $\begin{array}{l}\text { Type I probe: } \\
\text { Mmb303, } r=0.57, P<0.05\end{array}$ & $\begin{array}{l}\text { Type I probes: } \\
\text { Mb282, b_C11-403, Mm275, } r=0.70 \ldots \\
0.78, P<0.01\end{array}$ \\
\hline
\end{tabular}

Only significant correlations are shown. 
Table A2 |The microarray probe set used in the study and probe specificity.

\begin{tabular}{|c|c|}
\hline Name & Intended specificity \\
\hline BB51-302 & Methylobacter \\
\hline Mb292 & Methylobacter \\
\hline Mb282 & Methylobacter \\
\hline Mb_URC278 & Methylobacter \\
\hline Mb267 & Methylobacter \\
\hline $511-436$ & Methylobacter \\
\hline MbA486 & Methylobacter \\
\hline MbA557 & Methylobacter \\
\hline Mb_SL\#3-300 & Methylobacter \\
\hline Mb460 & Methylobacter \\
\hline Mb_LW12-211 & Methylobacter \\
\hline Mb_C11-403 & Methylobacter \\
\hline Mb271 & Methylobacter \\
\hline PS80-291 & Clone PS80 \\
\hline Est514 & Methylomicrobium-related clones \\
\hline Mm_pel467 & Methylomicrobium pelagicum \\
\hline Mb_SL-299 & Soda lake Methylobacter isolates and clones \\
\hline Mb_SL\#1-418 & Soda lake Methylobacter isolates and clones \\
\hline DS1_401 & Deep sea cluster \#1 \\
\hline Mm531 & Methylomonas \\
\hline Mm_ES294 & Methylomonas \\
\hline Mm_ES543 & Methylomonas \\
\hline Mm_ES546 & Methylomonas \\
\hline Mm_M430 & Methylomonas \\
\hline Mm_MV421 & Methylomonas \\
\hline Mm275 & Methylomonas \\
\hline Mm451 & Methylomonas \\
\hline peat_1_3-287 & Methylomonas-related peat clones \\
\hline Jpn284 & Clone Jpn 07061 \\
\hline Mmb303 & Methylomicrobium album \\
\hline Mmb259 & Methylomicrobium album + Landfill M. microbia \\
\hline Mmb562 & Mmb. album and Methylosarcina \\
\hline LP20-644 & Methylomicrobium-related clones \\
\hline la193 & Type I a (M. bacter-M. monas-M. microbium) \\
\hline la575 & $\begin{array}{l}\text { Type I a (M. bacter-M. monas-M. microbium-M. } \\
\text { sarcina) }\end{array}$ \\
\hline JRC4-432 & Japanese rice cluster \#4 \\
\hline MclT272 & Methylocaldum tepidum \\
\hline MclG281 & Methylocaldum gracile \\
\hline MclE302 & Methylocaldum E10 \\
\hline MclS402 & Methylocaldum szegediense \\
\hline Mcl408 & Methylocaldum \\
\hline $501-375$ & $\begin{array}{l}\text { Methylococcus-related marine and freshwater sed- } \\
\text { iment clones }\end{array}$ \\
\hline $501-286$ & $\begin{array}{l}\text { Methylococcus-related marine and freshwater sed- } \\
\text { iment clones }\end{array}$ \\
\hline USC3-305 & Upland soil cluster \#3 \\
\hline Mc396 & Methylococcus \\
\hline fw1-639 & $\begin{array}{l}\text { fw1 group: } M \text {. coccus- } M \text {. caldum related marine } \\
\text { and freshwater sediment clones }\end{array}$ \\
\hline fw1-641 & $\begin{array}{l}\text { fw1 group: } M \text {. coccus- } M \text {. caldum related marine } \\
\text { and freshwater sediment clones }\end{array}$ \\
\hline
\end{tabular}

\begin{tabular}{|c|c|}
\hline Name & Intended specificity \\
\hline fw1-286 & $\begin{array}{l}\text { fw1 group: } M \text {. coccus- } M \text {. caldum related marine } \\
\text { and freshwater sediment clones }\end{array}$ \\
\hline LW21-374 & LW21 group \\
\hline LW21-391 & LW21 group \\
\hline OSC220 & Finnish organic soil clones and related \\
\hline osc300 & Finnish organic soil clones and related \\
\hline JRC3-535 & Japanese Rice Cluster \#3 \\
\hline LK580 & fw1 group + Lake Konstanz sediment cluster \\
\hline JRC2-447 & Japanese Rice Cluster \#2 \\
\hline M90-574 & $\begin{array}{l}\text { M. coccus-M. caldum related marine and freshwa- } \\
\text { ter sediment clones }\end{array}$ \\
\hline M90-253 & $\begin{array}{l}\text { M. coccus-M. caldum related marine and freshwa- } \\
\text { ter sediment clones }\end{array}$ \\
\hline Mth413 & Methylothermus \\
\hline lb453 & $\begin{array}{l}\text { Type I b (M. thermus-M. coccus-M. caldum and } \\
\text { related) }\end{array}$ \\
\hline lb559 & $\begin{array}{l}\text { Type I b (M. thermus-M. coccus-M. caldum and } \\
\text { related) }\end{array}$ \\
\hline DS3-446 & Deep sea cluster \#3 \\
\hline JR2-409 & JR cluster \#2 (California upland grassland soil) \\
\hline JR2-468 & JR cluster \#2 (California upland grassland soil) \\
\hline JR3-505 & JR cluster \#3 (California upland grassland soil) \\
\hline JR3-593 & JR cluster \#3 (California upland grassland soil) \\
\hline Nc_oce4 26 & Nitrosococcus oceani \\
\hline USCG-225 & Upland soil cluster Gamma \\
\hline USCG-225b & Upland soil cluster Gamma \\
\hline Mcy233 & Methylocystis \\
\hline Mcy413 & Methylocystis \\
\hline Mcy522 & Methylocystis A + peat clones \\
\hline Mcy264 & Methylocystis \\
\hline Mcy270 & Methylocystis \\
\hline Mcy459 & Methylocystis \\
\hline Mcy255 & M. cystis B (parvus/echinoides/strain M) \\
\hline МсуМ309 & M. cystis strain $M$ and related \\
\hline МсуB304 & M. cystis B (parvus/echinoides/strain M) \\
\hline MsT214 & Methylosinus trichosporium OB3b and rel. \\
\hline Msi520 & M. trichosporium \\
\hline Msi269 & M. trichosporium \\
\hline MsS314 & Methylosinus sporium \\
\hline MsS475 & Methylosinus sporium \\
\hline Msi263 & $\begin{array}{l}\text { Methylosinus sporium + } 1 \text { Msi. trichosporium sub- } \\
\text { claster }\end{array}$ \\
\hline Msi423 & Methylosinus \\
\hline Msi294 & Methylosinus \\
\hline Msi232 & $\begin{array}{l}\text { M. sinus + most M. cystis-considered as additional } \\
\text { type II probe }\end{array}$ \\
\hline Peat264 & Peat clones \\
\hline 11509 & Type II \\
\hline 11630 & Type II \\
\hline xb6-539 & $\begin{array}{l}\text { Novel pmoA copy of type II and related environmen- } \\
\text { tal clones }\end{array}$ \\
\hline
\end{tabular}




\section{Table A2 | Continued}

\begin{tabular}{|c|c|}
\hline Name & Intended specificity \\
\hline LP21-190 & $\begin{array}{l}\text { Novel pmoA copy of type } I I \text { and related environmen- } \\
\text { tal clones }\end{array}$ \\
\hline LP21-260 & $\begin{array}{l}\text { Novel pmoA copy of type } I I \text { and related environmen- } \\
\text { tal clones }\end{array}$ \\
\hline NMcy1-247 & Novel pmoA copy of M. cystis \#1 $\left({ }^{*}\right)$ \\
\hline NMcy2-262 & Novel pmoA copy of M. cystis \#2 $\left({ }^{*}\right)$ \\
\hline NMsiT-271 & Novel pmoA copy of $M$. sinus trichpsporium $\left({ }^{*}\right)$ \\
\hline LP21-232 & $\begin{array}{l}\text { Novel pmoA copy of type } I I \text { and related environmen- } \\
\text { tal clones }\end{array}$ \\
\hline RA14-594 & RA14 related clones \\
\hline RA14-591 & RA14 related clones \\
\hline Wsh1-566 & Watershed + flooded upland cluster 1 \\
\hline Wsh2-491 & Watershed + flooded upland cluster 2 \\
\hline Wsh2-450 & Watershed + flooded upland cluster 2 \\
\hline B2rel251 & Methylocapsa-related clones \\
\hline B2-400 & Methylocapsa \\
\hline B2all343 & Methylocapsa and related clones \\
\hline B2all341 & Methylocapsa and related clones \\
\hline pmoAMO3-400 & Clone pmoA-MO3 \\
\hline ESR-579 & ESR (Eastern Snake River) cluster \\
\hline TUSC409 & Tropical upland soil cluster \#2 \\
\hline TUSC502 & Tropical upland soil cluster \#2 \\
\hline mtrof173 & Universal \\
\hline mtrof362-I & Methanotrophs \\
\hline mtrof661 & Methanotrophs \\
\hline mtrof662-I & Methanotrophs \\
\hline mtrof656 & Methanotrophs \\
\hline NmNc53 3 & Nitrosomonas-Nitrosococcus \\
\hline Nsm_eut 381 & Nitrosomonas eutropha \\
\hline PS5-226 & Nitrosomonas-Nitrosococcus related clones \\
\hline PI6-306 & Nitrosomonas-Nitrosococcus related clones \\
\hline NsNv207 & Nitrosospira-Nitrosovibrio \\
\hline NsNv363 & Nitrosospira-Nitrosovibrio \\
\hline Nit_rel47 1 & AOB related clones/probably methanotrophs \\
\hline Nit_rel22 3 & AOB related clones/probably methanotrophs \\
\hline ARC529 & AOB related clones/probably methanotrophs \\
\hline Nit_rel47 0 & AOB related clones/probably methanotrophs \\
\hline Nit_rel35 1 & AOB related clones/probably methanotrophs \\
\hline Nit_rel30 4 & Crenothrix and related \\
\hline M84P105-451 & Environmental clones of uncertain identity \\
\hline WC306_54-385 & Environmental clones of uncertain identity \\
\hline M84P22-514 & Environmental clones of uncertain identity \\
\hline gp23-454 & Environmental clones of uncertain identity \\
\hline MR1-348 & Environmental clones of uncertain identity \\
\hline gp619 & Environmental clones of uncertain identity \\
\hline gp391 & Environmental clones of uncertain identity \\
\hline gp2-581 & Environmental clones of uncertain identity \\
\hline RA21-466 & $\begin{array}{l}\text { Clone RA21 - environmental clone of uncertain } \\
\text { identity }\end{array}$ \\
\hline
\end{tabular}

${ }^{*}$ Assignment based on limited information from cultivated methanotrophs. 


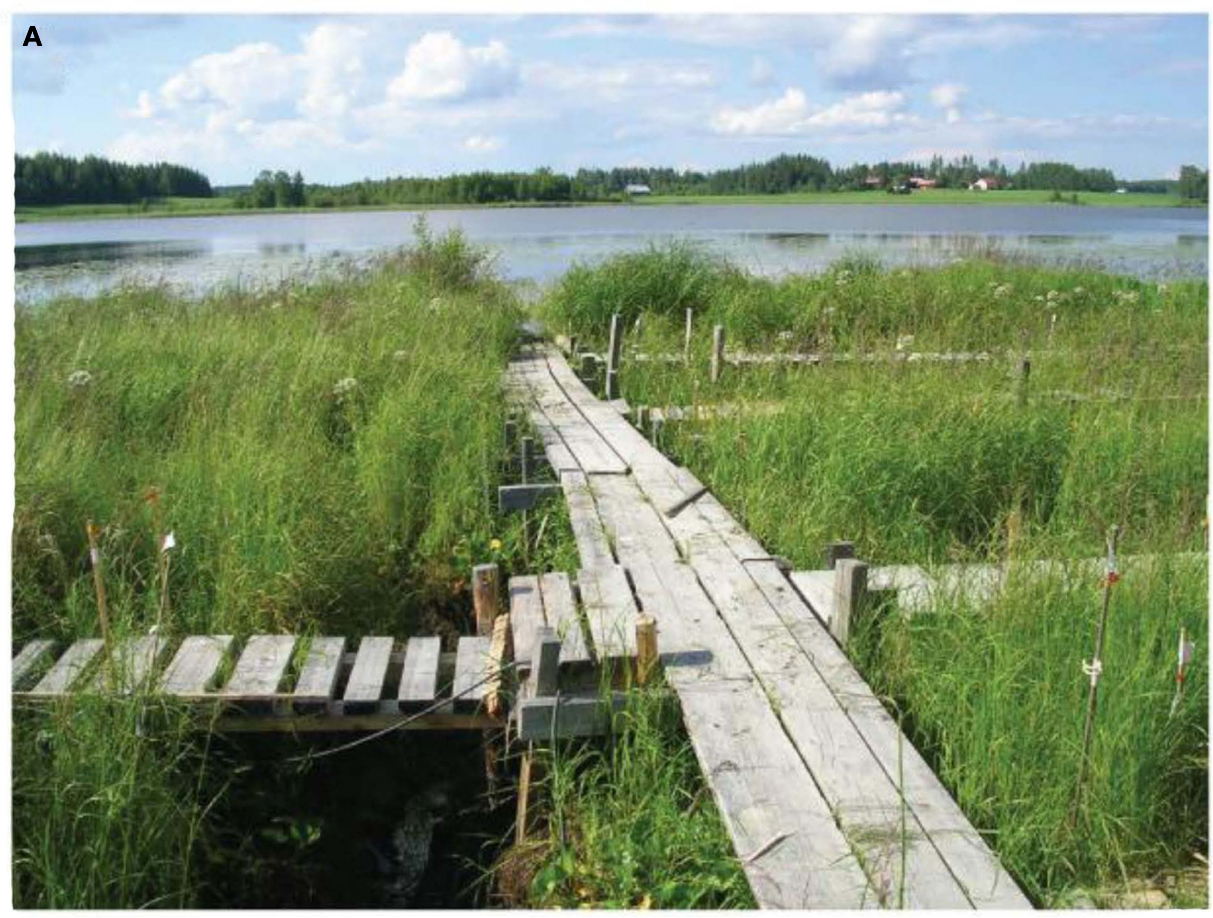

B

Nitrogen loading:

- $2.5 \mathrm{~g} \mathrm{~N} \mathrm{~m}^{-2}\left(\mathrm{NH}_{4} \mathrm{NO}_{3}\right)$ dose

loaded four times in growing season.

- Equal volume of $\mathrm{H}_{2} \mathrm{O}$ loaded

at the same time to control plots.

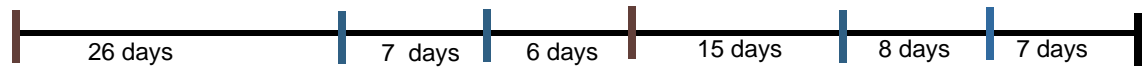

Soil sampling before manipulation: J un 7th
Soil sampling during manipulation: J ul 17th
Soil sampling

after manipulation:

Aug 16th

\section{Soil sampling from control and manipulated plots:}

FIGURE A1 | (A) The littoral wetland of Lake Kevätön in July 2007. For experiment, three control and three manipulated plots of $1.44 \mathrm{~m}^{2}$ were established to area having equal water level and vegetation. The chambers for measurements of in situ $\mathrm{CH}_{4}$ fluxes were inserted into study plots 2 weeks before the experiment. Soil sampling and in situ $\mathrm{CH}_{4}$ flux measurements were taken from boardwalks to omit disturbance of the soil. (B) Soil sampling and nitrogen loading scheme. Time points of soil samplings and nitrogen/water loading are colored with brown and blue respectively. Methane fluxes were measured three times before, during and after the nitrogen loading (with 1-2 week intervals). During the $\mathrm{N}$ loading period, fluxes were measured before addition of $\mathrm{NH}_{4} \mathrm{NO}_{3}$ solution or distilled water. 


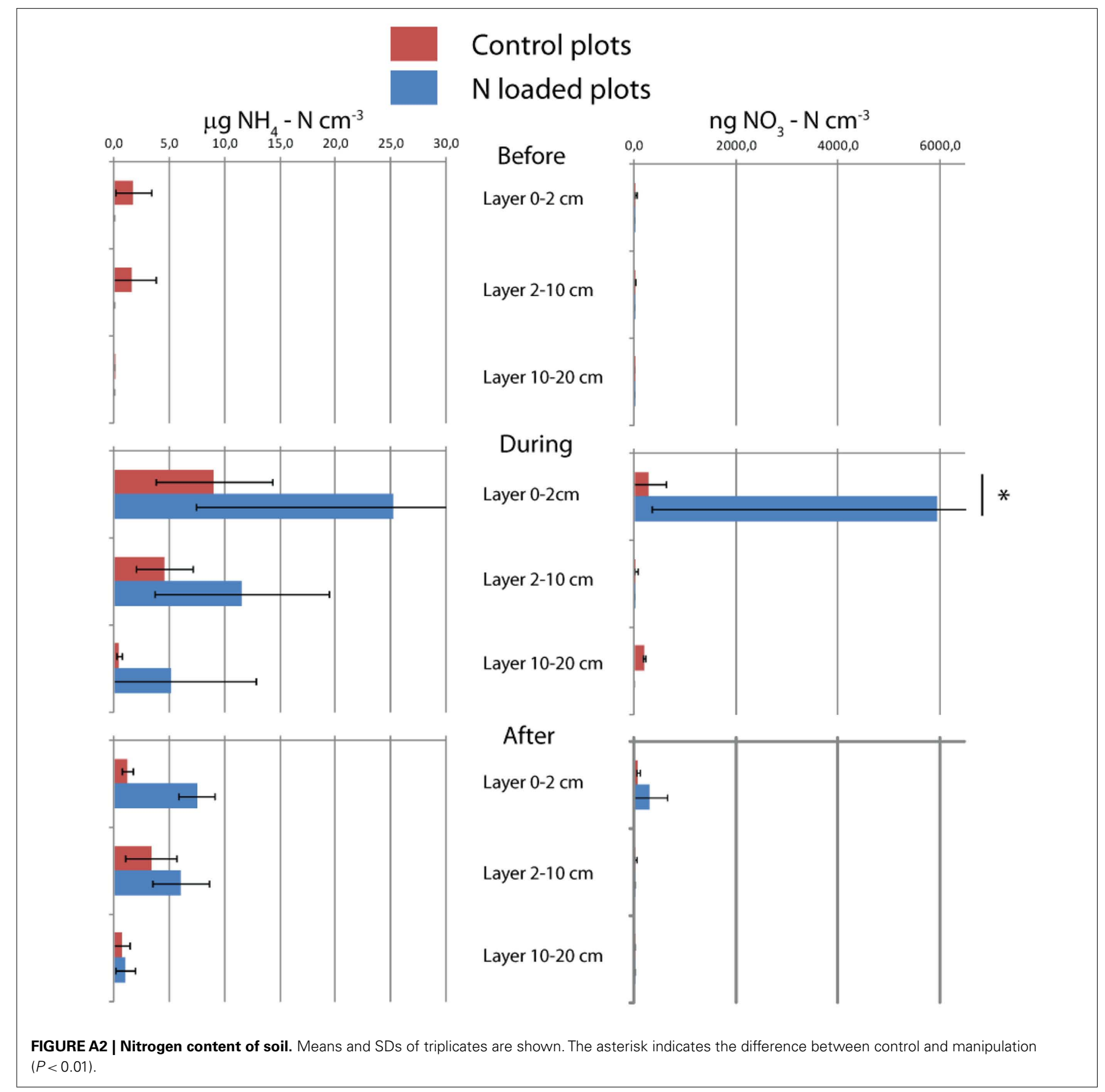




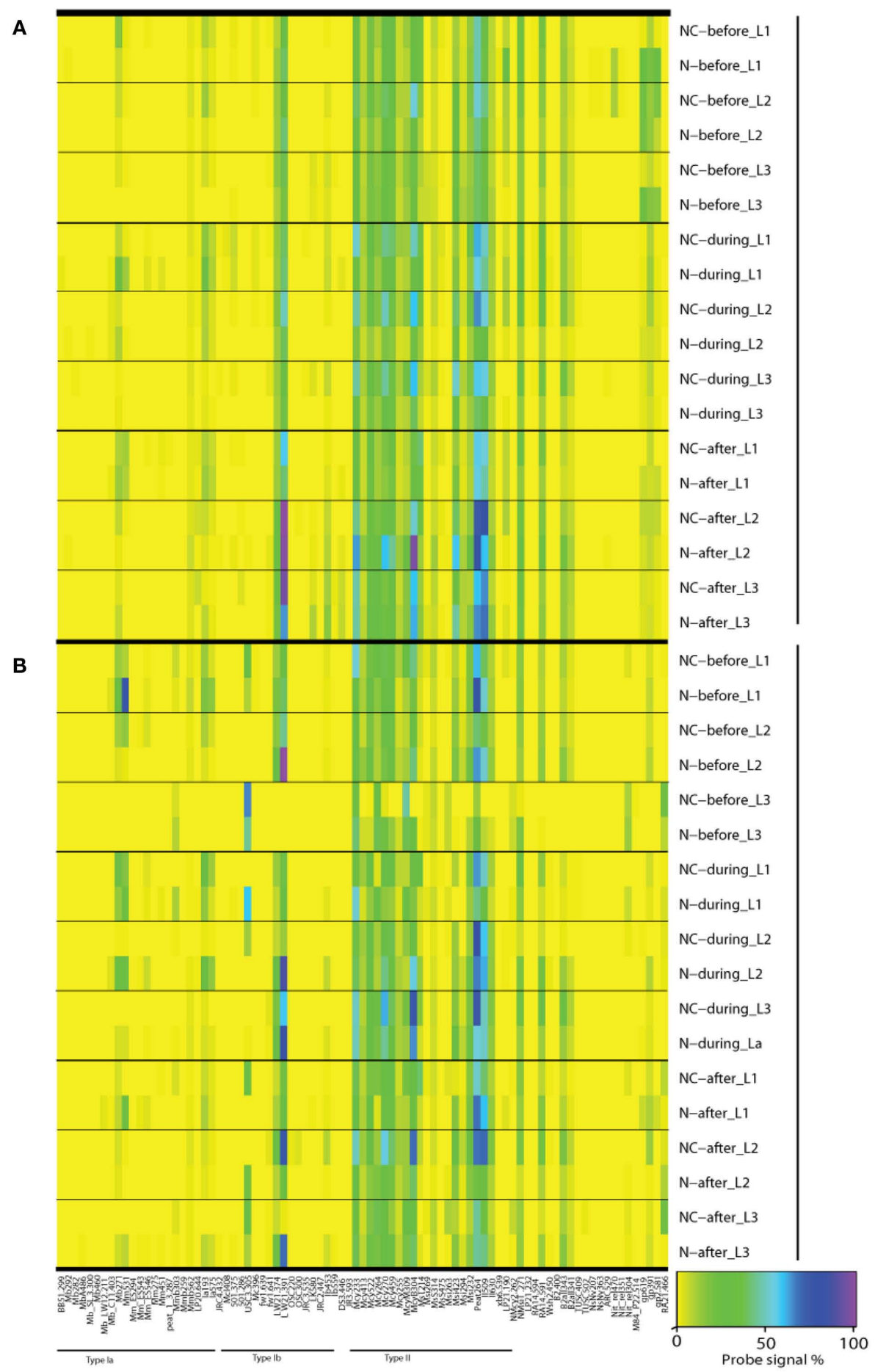

FIGURE A3 | Microarray results of community composition [(A), DNA] and functional diversity [(B), RNA] of methanotrophs before, during, and after nitrogen loading. Averages of triplicate plots are shown. A value of 100 (purple) indicates the maximum and a value of 0 (yellow) indicates the minimum signal intensity of a probe against reference hybridizations determined for each probe individually (Bodrossy et al., 2003). Only probes having positive hybridization are shown. $\mathrm{N}$ denotes nitrogen loading plots, NC control plots, L1 0-2 cm layer, L2 2-10 cm layer, and L3 10-20 cm layer. 


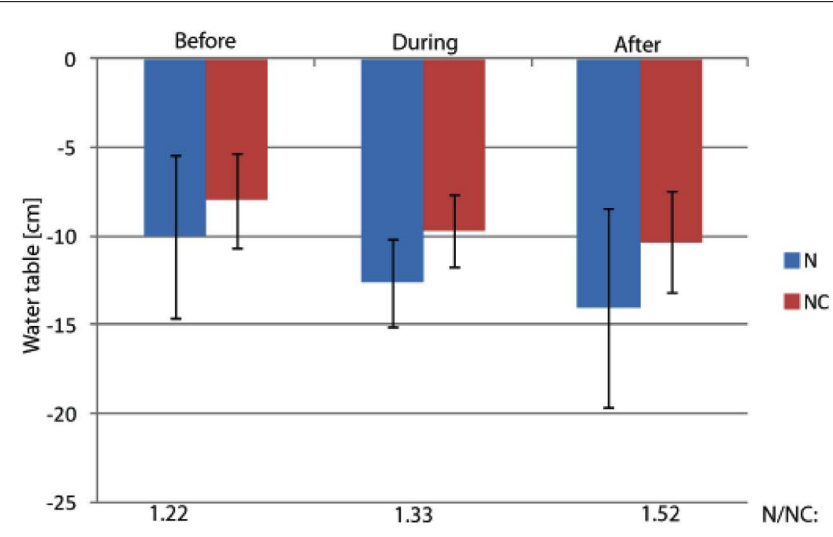

FIGURE A4 | The water table in the study plots. The water table was measured from perforated plastic tubes inserted in soil inside the study plots. The ratio of mean water level of nitrogen loaded and control plots is marked on bottom of the figure.

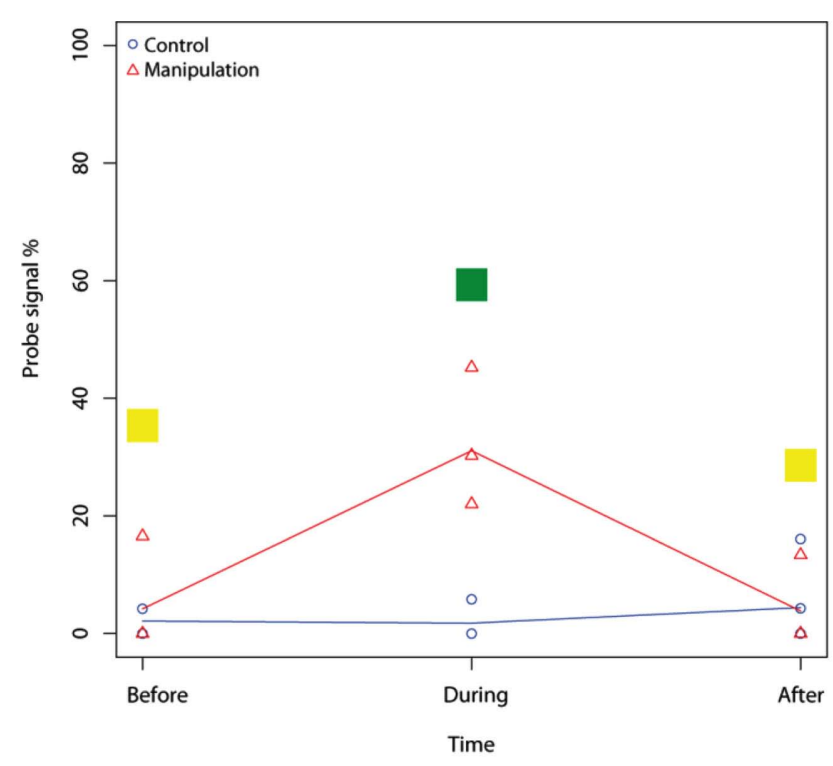

FIGURE A5 | Example of a mixed-effect model result for the microarray probe Mb271 (RNA samples, 2-10 cm). Mixed-effect model comparison evaluated the difference between two fitted models, the control and the manipulation model. In Figure 3A, the result of each comparison is shown in color, thus, no effect on studied microarray probe by nitrogen $=$ yellow, stimulated effect $=$ green, inhibited effect $=$ red, and for negative probes $=$ blue . 